\title{
Spatial and temporal variation in microcystin concentrations during perennial bloom of Planktothrix agardhii in a hypertrophic lake
}

\author{
B. Pawlik-Skowrońska ${ }^{1,2^{*}}$, J. Pirszel ${ }^{1,3}$, R. Kornijów ${ }^{2}$ \\ ${ }^{1}$ Centre for Ecological Research, P.A.S. at Dziekanów Leśny, Experimental Station, Niecala 18, 20-080 Lublin, Poland. \\ 2 Department of Hydrobiology, University of Life Sciences at Lublin, Dobrzańskiego 37, 20-262 Lublin, Poland \\ ${ }^{3}$ present address: Military Institute of Chemistry and Radiometry, Gen A. Chruściela 105, 00-910 Warsaw, Poland
}

\begin{abstract}
Temporal and spatial variation in the concentrations of intra- and extra-cellular microcystins were studied in a hypertrophic lake with bloom of Planktothrix agardhii (Gomont) Anagnostidis et Komarek. Concomitantly with increase in water temperature (from 2 to $20^{\circ} \mathrm{C}$ ) abundance of $P$. agardhii increased from $1.9 \times 10^{5}$ to $4.3 \times 10^{7}$ trichomes $\mathrm{L}^{-1}$. In autumn, in spite of temperature lower $\left(14^{\circ} \mathrm{C}\right)$ than in summer it was still very high. Mass development of P. agardhii (to $6 \times 10^{6} \mathrm{~L}^{-1}$ and higher) caused a severe decrease in water transparency (to $0.5-0.2 \mathrm{~m}$ in summer/autumn). The cyanobacterium density was relatively uniform within water column; only in summer (July) it was significantly higher (by about 30\%) in surface than in bottom layer. From spring to autumn microcystins (MCs) were mainly biomass-bound (up to $90 \mu \mathrm{g}$ MC-LR equiv. $\mathrm{L}^{-1}$ ), whereas the level of extra-cellular toxins was much lower (up to $2 \mu \mathrm{g} \mathrm{L}^{-1}$ ) and relatively stable. Only in winter, high amounts of MCs $\left(11.3 \mu \mathrm{g} \mathrm{L}^{-1}\right.$ ) were released from decaying biomass into water. The increasing concentrations of biomass-bound microcystins in the lake water positively correlated $\left(\mathrm{R}^{2}=0.9863 ; \mathrm{y}=-0.1285 \mathrm{x}^{2}+7.14 \mathrm{x}\right)$ with the abundance of $P$. agardhii and the highest concentrations of the intracellular MC fraction were found during the exponential phase of $P$. agardhii growth. In addition, the surface-sampled biomass of $P$. agardhii contained in autumn 2-fold more MCs $\left(2.75 \mu \mathrm{g}\right.$ MC-LR equiv. per $10^{6} P$. agardhii trichomes) than the bottom-sampled one (1.41 $\mu \mathrm{g}$ MC-LR equiv. per $10^{6}$ trichomes). This is the first report showing that despite the homogenous distribution of $P$. agardhii in water column of a shallow lake, various seasonal and spatial distributions of both extra-cellular and intracellular fractions of microcystins occur.
\end{abstract}

Keywords: cyanobacterial bloom, hypertrophic lake, intra- and extra-cellular microcystins, Planktothrix agardhii

\section{Introduction}

In European shallow turbid lakes and reservoirs a dominance of the filamentous cyanobacterium Planktothrix agardhii (Gomont) Anagnostidis et Komarek has been frequently reported (Rücker et al. 1997, Wiedner et al. 2002, Nixdorf et al. 2003, Pawlik-Skowrońska et al. 2004, Akcaalan et al. 2006). P. agardhii is a common hepatotoxin producer with higher microcystin (MC) content per dry weight than Microcystis spp (Fastner et al. 1999a). As a consequence of genotypic differentiation Planktothrix populations consist of many clonal strains with considerable variability of contents and numbers of structural microcystin variants (Fastner et al. 1999b, Laub et al.2002, Welker et al.2004). P.agardhii may pro-

\footnotetext{
* Corresponding author : E-mail: pawlik@ poczta.umcs.lublin.pl
}

duce at least 25 different isoforms of microcystins that are heptapeptides (Mbedi et al. 2005 ) and within one population non-producers and microcystin-producers, which are morphologically identical, usually coexist. As reported by Welker et al. (2004) 18 strains of P. agardhii were isolated from a single sample of lake water, but only in 7 of them microcystins were detected. As recently established, one clonal strain may produce several various MC variants of different toxicity (Tonk et al. 2005). Therefore, in natural water bodies species/strain composition of cyanobacterial communities is largely responsible for total microcystin concentration. Several laboratory studies revealed that microcystin production may also vary within a range of environmental factors like nutrient concentration, light and temperature (Watanabe \& Oishi 1985, Sivonen 1990, Kaebernick et al. 2000, Wiedner et al 2003). The aim of this paper was 
to study seasonal dynamics and spatial distribution of biomass-bound (intracellular) and extra-cellular microcystins in a "phytoplankton-dominated", hypertrophic lake with perennial blooms of $P$. agardhii.

\section{Material and methods}

\section{Study area and sampling}

Shallow Syczyńskie Lake (51 ${ }^{\circ} 17^{\prime} 12^{\prime \prime} \mathrm{N} ; 23^{\circ} 14^{\prime} 16^{\prime \prime}$ E ) is located in Eastern Poland (Polesie Lubelskie region). Morphometric parameters of the lake (max depth $2.9 \mathrm{~m}$; mean depth $0.9 \mathrm{~m}$ ) has been previously published (Kornijów \& Pęczuła 2005). Water samples were taken from the lake surface and bottom (10-15 cm above the sediment) at the depth 2.4-2.8 $\mathrm{m}$ in March - October 2004. In winter, surface layer of lake sediment was additionally sampled. Aliquots of water samples were analysed for ammonia, nitrate and orthophosphates by spectrophotometric methods. Temperature, $\mathrm{pH}$, conductivity, oxygen saturation and water transparency (Secchi depth) were also measured.

\section{P. agardhii abundance}

Potentially toxic cyanobacteria in the lake water were identified by light microscopy. Abundance of P. agardhii was determined according to Utermőhl (1958) method and has been given in terms of trichomes $\mathrm{L}^{-1} .100 \mu \mathrm{m}$ trichome was used as a reference. Dry weight of the surface scum consisted of $P$. agardhii was determined after overnight drying at $90{ }^{\circ} \mathrm{C}$.

\section{Determination of total microcystins by GC/MS}

Due to possible presence of numerous different variants of microcystins in P. agardhii biomass, their total concentrations in a filtered lake water (extra-cellular $\mathrm{MCs}$ ) and in a phytoplankton biomass (biomass-bound fraction) were determined by gas chromatography /mass spectrometry according to Harada et al. (1996) and Kaya \& Sano (1999). The method is based on oxidation of Adda (amino-acid responsible for biological activity of microcystins) to 2-methyl-3-methoxy-4-phenylbutyric acid (MMPB) and determination of MMPB as methyl ester. Phytoplankton biomass was separated from 0.5 - 1 $\mathrm{L}$ of the lake water by its concentration on $\mathrm{GF} / \mathrm{C}$ filters (Whatman, UK) to $1 \mathrm{ml}$. Filtered water samples and phytoplankton biomass were kept at $-20{ }^{\circ} \mathrm{C}$ prior extraction for microcystin analysis. Both the biomass and filtered and evaporated (at $40^{\circ} \mathrm{C}$ ) lake water samples were extracted with acidified $75 \%$ methanol . The biomass was additionally disrupted by means of ultrasonication
(3- times for $5 \mathrm{~min}, 50 \mathrm{~W}$ ) and extracts were collected. The obtained extracts were evaporated under inert gas; sub-samples were oxidised with $\mathrm{NaIO}_{4}$ and $\mathrm{KMnO}_{4}$, extracted with n-hexane and derivatised with $14 \%$ $\mathrm{BF}_{3}$-methanol (Kaya \& Sano 1999; Tsuji et al. 2001). As a modification, phenylbutyric acid (PB) was used as internal standard after oxidation step. Derivatised samples were dissolved in n-hexane and $1 \mu$ samples in organic phase were subjected to GC/MS analysis (Saturn 2000, Varian). VA-5MS capillary column (30 m x 0.25 $\mathrm{mm} ; 0.25 \mu \mathrm{m}$ ) was used. In EI-MS mode the identification and quantification of MMPB methyl ester was based on ions at m/z 91, 131 and 190; for PB methyl ester 91, 104 and $146 \mathrm{~m} / \mathrm{z}$ were used. Identification of MMPB and PB was confirmed by CI-MS at m/z 191 and 147, respectively. Acetonitrile was used as reagent gas. For microcystin quantification standard MC-LR (Calbiochem) was used. Total microcystin concentrations were expressed as equivalents of MC-LR. Determinations were made in triplicates.

\section{Statistical analyses}

Statistical tests were carried out using the software package STATGRAPHICS plus 5.0. The data were tested for homogeneity of variance and normality and subjected for one-factor analysis of variance (ANOVA). Differences between means were determined by Tukey's post hoc multiple range test at $\mathrm{P}<0.05$ for this procedure. The variation about means is displayed graphically as \pm the standard error of the mean (SE).

\section{Results}

Such habitat characteristics of lake Syczyńskie like shallowness and high contents of dissolved nutrients (Table 1) were the factors that supported mass development of the typical of turbid water, $\mathrm{N}_{2}$ non-fixing cyanobacterium P. agardhii (Fig.1A). Throughout the year of study, the temperature, $\mathrm{pH}$ and conductivity did not differed between surface and bottom layers of the lake water, however, bottom layers contained higher concentrations of dissolved orthophosphates and ammonium ions and lower oxygen saturation than the surface layers (Fig.1B, Table 1). The very high density of $P$. agardhii occurred in water column throughout the year and increased from $1.9 \times 10^{5}$ trichomes $\mathrm{L}^{-1}$ in winter(March) to $4.3 \times 10^{7}$ trichomes $\mathrm{L}^{-1}$ by September (Fig.1A). Vertical distribution of $P$. agardhii in the lake was almost uniform from winter to autumn. Microscopic observations revealed that in the ice-covered lake numerous trichomes of $P$. agardhii over-wintered on the lake sediments. Significantly higher density (by about $30 \%$ ) 
Table 1. Annual average values and ranges (*) of some physico-chemical parameters in different water layers of lake Syczyńskie (2004).

\begin{tabular}{lcc}
\hline \multicolumn{1}{c}{ Parameter } & Surface layer & Bottom layer \\
\hline $\mathrm{pH}$ & 8.3 & 8.3 \\
& $*(8.0-8.7)$ & $*(8.0-8.7)$ \\
Conductivity $(\mu \mathrm{S} / \mathrm{cm})$ & 548 & 527 \\
& $*(511-599)$ & $*(503-551)$ \\
Oxygen saturation & 123.7 & 85.8 \\
$(\%)$ & $*(111-133.5)$ & $*(81.5-91)$ \\
$\mathrm{NH}_{4}-\mathrm{N}(\mu \mathrm{M})$ & 33.4 & 42.8 \\
& $*(18.1-87.5)$ & $*(20.2-105.8)$ \\
$\mathrm{NO}_{3}-\mathrm{N}(\mu \mathrm{M})$ & $<71.4$ & $<71.4$ \\
$\mathrm{PO}_{4}-\mathrm{P}(\mu \mathrm{M})$ & 2.0 & 3.2 \\
& $*(0.2-8.2)$ & $*(0.5-10.8)$ \\
\hline
\end{tabular}

in surface than in bottom water layer was observed only in July. Water transparency and light conditions in water column decreased considerably from $0.9 \mathrm{~m}$ (May) to 0.2 - $0.3 \mathrm{~m}$ (July-October) at increase in water temperature from 16 to $20^{\circ} \mathrm{C}$ (Fig. 1C) and approximate 210 - fold increase in the density of $P$. agardhii population (Fig.1A).

Taxonomic analysis of phytoplankton in this lake revealed that population of $P$. agardhii was the main and almost only source of microcystins throughout the year, with exception of the period June /July, when several Anabaena spp - potential MC producers occurred. Anabaena spp abundance was, however, 20 - 40- fold lower than that of $P$. agardhii (data not shown) and completely disappeared already in August when $P$. agardhii abundance was still very high (Fig.1A). Monthly changes in microcystin concentrations (both extra-cellular and biomass-bound fractions) in the lake are presented in Fig. 2A. In March, at the lowest water temperature, the highest extra-cellular microcystin concentration (approx.11 $\mu g$ MC-LR equiv. $\mathrm{L}^{-1}$ ) and low levels of the biomass-bound fraction (approx.1.75 $\mu \mathrm{g}$ MC-LR equiv. $\mathrm{L}^{-1}$ ) were found. The high level of extra-cellular MCs observed in winter decreased 5-times with increasing temperature (from 2 to $12^{\circ} \mathrm{C}$ ) in spring and stayed relatively constant $\left(1-2 \mu \mathrm{g}\right.$ MC-LR equiv. $\left.\mathrm{L}^{-1}\right)$ in summer and autumn. At increasing densities of $P$. agardhii from May to July increasing concentrations of biomass-bound microcystins in the lake water were observed (Figs.1A, $2 \mathrm{~A})$. In summer and autumn the biomass-bound microcystins always prevailed over the extra-cellular MC fraction. Even in early autumn, when water temperature decreased from 20 to $14^{\circ} \mathrm{C}$ the level of the intracellular microcystins was high and relatively stable. Interestingly, during logarithmic growth of $P$. agardhii in
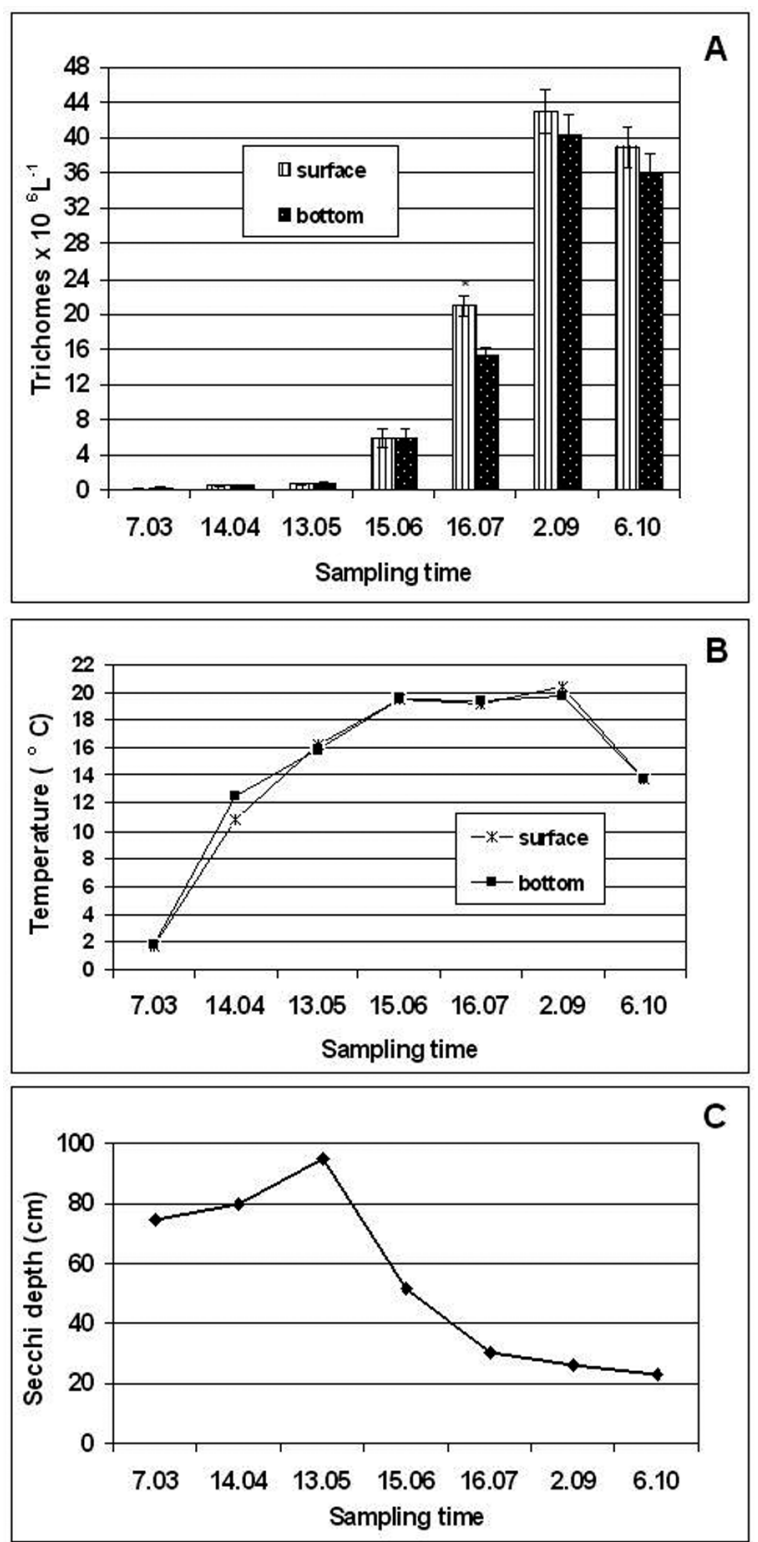

Fig. 1. Differences in: (A) spatial distribution of $P$. agardhii in lake Syczyńskie; (B) temperatures of surface and bottom water layers; (C) water transparency. Asterisk symbol (*) in A indicates significantly higher abundance of the cyanobacterium in surface layer (at $\mathrm{P}<0.05)$.

May-July, while water transparency decreased from 0.9 to $0.3 \mathrm{~m}$, the cyanobacterial biomass predominated by $P$. agardhii contained more microcystins $(4.7-7.0 \mu \mathrm{g}$ MC-LR equiv. per $10^{6} P$. agardhii trichomes) than the biomass sampled in other studied seasons (Fig. 2A). 

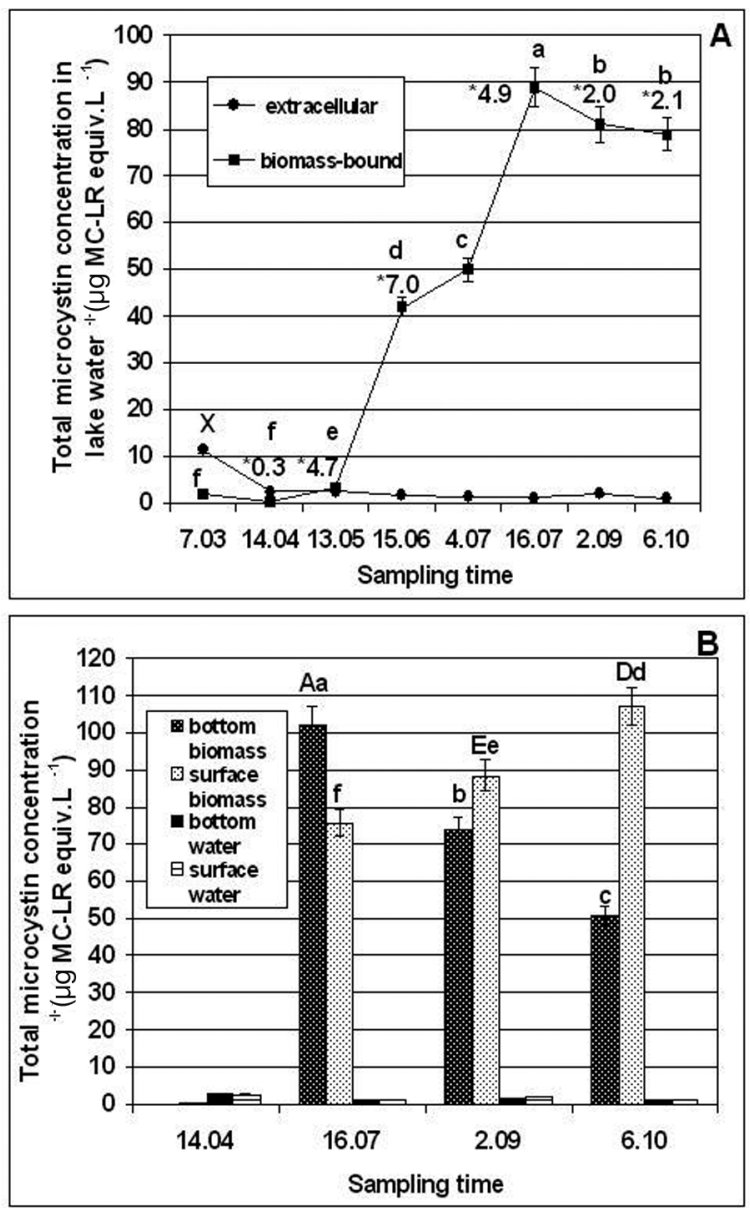

Fig. 2. Changes in the average concentrations of microcystins (biomass-bound and extra-cellular fractions) in water column of the lake (A); distribution of the biomass-bound and extra-cellular microcystins in different water layers (B). All data are expressed as means $\pm \mathrm{SE}, \mathrm{n}=3-4$. 2A- asterisk symbols (*) indicate the biomass-bound MCs referred to $10^{6}$ trichomes of P. agardhii; different lower case letters (abcdef) indicate significant differences between contents of the biomass-bound MCs in lake water $($ at $\mathrm{P}<0.05) ; \mathrm{X}$ designates statistically higher concentration of extra-cellular MCs in winter than in other seasons (at $\mathrm{P}<0.05$ ). $2 \mathrm{~B}$ - letters designate significant differences in concentrations of the biomass-bound MCs found at different sampling terms (at $\mathrm{P}<0.005$ ) in groupings: abc (bottom-sampled biomass); def (surface-sampled biomass); ADE designate significantly higher concentrations of the biomass-bound MCs in the particular water layer.

More detailed studies on spatial distribution of microcystins in water column carried out from spring to autumn (Fig. 2B) revealed non-essential differences in extra-cellular MC concentrations between bottom and surface water layers. However, in summer and autumn, at very low water transparency $(\leq 0.2 \mathrm{~m})$ caused by the very dense bloom of $P$. agardhii, the cyanobacterial biomasses sampled from bottom and surface water layers differed in microcystin contents. During four months of the very dense bloom of P. agardhii (July-October) the intracellular MC content in bottom-sampled biomass gradually decreased but in the surface-sampled one it increased (Fig. 2B). In October, when P. agardhii vertical distribution in water column was almost uniform ( Fig.1A), the surface-sampled biomass of the bloom contained approx. 2-fold more microcystins (2.75 $\mu \mathrm{g}$ MC-LR equiv. per $10^{6} P$. agardhii trichomes) than the bottom-sampled one (1.41 $\mu \mathrm{g}$ MC-LR equiv. per $10^{6}$ trichomes).

\section{Discussion}

In nutrient-rich, shallow, freshwater bodies population of the microcystin producer $P$. agardhii may reach very high densities being a predominant cyanobacterial species in summer/autumn seasons (Wiedner et al. 2002). The studied lake Syczyńskie was predominated by filamentous cyanobacteria (Oscillatoriales) with $P$. agardhii reaching in summer/autumn about $80 \%$ of the phytoplankton biomass and $96 \%$ of the abundance of all potentially toxic cyanobacteria (Wiśniewska et al. 2007). The non-toxic Limnothrix redekei Van Goor predominated only in early spring (Kornijów \& Pęczuła 2005, Wiśniewska et al. 2007). In a shallow eutrophic French lake and in a dam reservoir in Poland densities of P. agardhii reached $4.5 \times 10^{6}$ trichomes L-1 (Briand et al. 2002) and $8 \times 10^{6}$ trichomes L-1 (Pawlik-Skowrońska et al. 2004), respectively. In the lake Syczyńskie, which is extremely rich in ammonium ions, $P$. agardhii created perennial, dense bloom of even higher density $\left(4.3 \times 10^{7}\right.$ trichomes $\left.\mathrm{L}^{-1}\right)$. This toxin-producing cyanobacterium is able to adapt to low light and low temperatures (Rückeret al. 1997) and therefore it may occur at high densities in winter both in water and sediments of the ice-covered lakes. Similar observation was reported for another potentially toxic cyanobacterium Microcystis (Verspagen et al. 2004).

The highest concentration of extra-cellular microcystins found in the water of the lake Syczyńskie in winter, at the lowest $P$. agardhii abundance, suggests, that the majority of the summer population of the cyanobacterium decayed in the coldest season and microcystins were released into water and lake sediments. Under field conditions microcystins are normally considered to be confined within cyanobacterial cells and enter the surrounding water after cell death, as it has been recently proved under laboratory conditions in Microcystis aeruginosa (Rohrlack \& Hyenstrand 2007). Extra-cel- 
lular MCs in the lake water were relatively persistent and even in spring (at temperatures up to $12^{\circ} \mathrm{C}$ ) they quantitatively dominated in the lake water over the biomass-bound fraction. The population of $P$. agardhii in Lake Syczyńskie was able to produce high amount of microcystins (approx.1.1 mg MC g ${ }^{-1} \mathrm{DW}$ of surface scum; Wiśniewska et al. 2007) that was however, 2-times lower than the MC content $\left(2.8 \mathrm{mg} \mathrm{MC} \mathrm{g}^{-1} \mathrm{DW}\right)$ reported for a seston of P. agardhii-dominated lake in Germany (Wiedner et al. 2002). It can be explained by the fact that even in one population of $P$. agardhii several strains of different genotypes and abilities to produce microcystins occur (Kurmayer et al. 2004). Morphologically identical genotypes of $P$. agardhii may differ also in other features like ability to produce stronger or weaker gas vesicles (Beard et al., 2000), what may cause different distribution of the cyanobacterium and its toxins in water column. To the best of our knowledge, very little is known on spatial and temporal distribution of microcystins in water layers of hypertrophic, polymictic lakes (Park et al., 1998), especially, dominated by P. agardhii blooms. The extra-cellular MC concentrations found in the Lake Syczyńskie in summer were very low in comparison with the biomass-bound toxins and similar to those reported in the hypertrophic lake Suwa (Japan) with Microcystis bloom (Park et al.1998) and in the Langer See in Germany (Wiedner et al. 2002). As stated in this work, $P$. agardhii bloom did not collapse at decreased water temperatures in early autumn, and $P$. agardhii trichomes died only partially in frosty winter. Taking into account the level of the biomass-bound MC in autumn (about $80 \mu \mathrm{g}$ MC-LR equiv. $\mathrm{L}^{-1}$ ) and the extra-cellular MC concentration in winter $\left(11 \mu \mathrm{g}\right.$ MC-LR equiv. $\left.\mathrm{L}^{-1}\right)$, it may be supposed that only about $14 \%$ of the intracellular toxins was released into water during partial bloom decay. However, such number may be underestimated because the released microcystins can be adsorbed on lake sediments (Rapala et al. 1994, Tsuji et al. 2001) and/or degraded by heterotrophic bacteria (Harada et al. 2004). As presented in this paper, the extra-cellular MC concentration gradually decreased in warmer spring months reaching a constant, low level, most probably, due to increased microbial activity (Harada et al. 2004). However, most MCs produced by $P$. agardhii stayed intracellular until following winter.

Vertical distribution of P. agardhii in the studied lake was almost homogenous, whereas MC distribution was not. Surprisingly, in September-October, at quantitatively negligible records of other potentially toxic cyanobacteria (Wiśniewska et al. 2007), P. agardhii biomass sampled from the surface and bottom water layers, contained different amounts of microcystins. The surface-sampled biomass of $P$. agardhii, which was better illuminated, contained 2-fold higher amounts of MCs than the self-shaded bottom-sampled one. The observed, for the first time under natural conditions, phenomenon is consistent with recent reports on dependence of MC production in the isolated strain of $P$. agardhii on light intensities (Tonk et al. 2005). It has been found that high light intensities caused increased production of some variants of microcystins, especially MC-DeLR, which is more toxic than other MC variants. Similar observation was reported in the case of Microcystis strain PCC 7806 and M. aeruginosa ( Kaebernick et al. 2000, Wiedner et al. 2003, Gerbersdorf 2006) in that photosynthetically active radiation revealed a positive effect on toxin production. Competition for light is an important selective factor in phytoplankton communities in eutrophic waters and it has been recently experimentally proved between toxic and non-toxic strains of Microcystis aeruginosa (Kardinaal et al. 2007). The higher content of intracellular MCs found in the surface-sampled biomass of $P$. agardhii than in the bottom-sampled one may also suggest that MC can serve, to some extent, for protection against exceeded intensity of UV/Vis radiation. Such assumption is supported by reports showing that increased transcription of $\mathrm{MC}$ genes responsible for $\mathrm{MC}$ synthesis occurs not only under increasing light intensity (Kaebernick et al. 2000) but also under prolonged exposure to UV radiation (Kimetal.2005). As reported by Van Donk et al. (2001) Planktothrix sp growth was not inhibited by UV radiation and was much more UV- resistant than that of picocyanobacteria and other small algae which do not produce microcystins .

The obtained results show that in shallow, polymictic lakes, despite almost uniform, vertical distribution of $P$. agardhii, the cyanobacterium-produced microcystins have different temporal and spatial distribution. The extra-cellular microcystins quantitatively dominate in colder seasons whereas the biomass-bound toxins in warmer seasons and thus they may variously influence lake biocenosis.

\section{Acknowledgements.}

Authors thank to B. Stępień and A. Adamczyk for their excellent technical assistance.

\section{References}

Akcaalan R., Young F.M., Metcalf J.S., Morrison L.F., Albay M. \& Codd G.A. 2006.- Microcystin analysis in single filaments of Planktothrix spp. in laboratory cultures and environmental blooms. Wat. Res. 40, 1583-1590.

Beard S.J., Davis P.A., Iglesias Rodroguez D., Skulberg O.M. \& Walsby A.E. 2000.- Gas vesicles genes in Planktothrix spp. from Nordic lakes: strains with weak gas vesicles possess a longer variant of gvpC. Microbiol.-UK., 146, 2009- 2018. 
Briand J.F., Robillot C., Quiblier-Lloberas C. \& Bernard, C. 2002.A perennial bloom Planktothrix agardhii (Cyanobacteria) in a shallow eutrophic French lake: limnological and microcystin production studies. Arch.Hydrobiol. 153, 605-622.

Fastner J., Neumann U., Wirsing B., Weckesser J., Wiedner C., Nixdorf B. \& Chorus I. 1999a. -Microcystins (hepatotoxic heptapeptides) in German freshwater bodies. Environ. Toxicol. 14, 13-22.

Fastner J., Erhard M., Carmichel W.W., Sun F., Rinehart K.L., Ronicke H. \& Chorus I. 1999b. -Characterization and diversity of microcystins in natural blooms and strains of the genera Microcystis and Planktothrix from German freshwaters. Arch. Hydrobiol. 145, 147-163.

Gerbersdorf S.U. 2006.- An advanced technique for immuno-labelling of microcystins in crysectioned cells of Microcystis aeruginosa PCC 7806 (Cyanobacteria): implementations of an experiment with varying light scenarios and culture densities. Toxicon 47, 218-228.

Harada K.I., Imanishi S., Kato H., Mizuno M., Ito E. \& Tsuji K. 2004.- Isolation of Adda from microcystin-LR by microbial degradation. Toxicon 44, 107-109.

Harada K-I., Murata H., Qiang Z., Suzuki M. \& Kondo F. 1996.Mass spectrometric screening method for microcystins in cyanobacteria. Toxicon $34,701-710$.

Kaebernick M., Neilan B.A., Börner T. and Dittmann E. 2000.Light and the transcriptional response of the microcystin biosynthesis gene cluster. Appl. Environ. Microbiol. 66, 3387-3392.

Kardinaal W.E.A., Tonk L., Janse I., Hol S., Slot P., Huisman J. \& Visser P.M. 2007.- Competition for light between toxic and nontoxic strains of the harmful cyanobacterium Microcystis. Appl. Environ. Microbiol. 73, 2939-2946.

Kaya K. \& Sano T. 1999.- Total microcystin determination using erythro-2-methyl-3-(methoxy- $\left.\mathrm{d}_{3}\right)$-4-phenylbuttyric acid $\left(\mathrm{MMPB}-\mathrm{d}_{3}\right)$ as the internal standard. Anal. Chim. Acta 386, 107-112.

Kim H.R., Kim C.K., Ahn T.S., Yoo S.A. \& Lee D.H. 2005.- Effects of temperature and light on microcystin synthetase gene transcription in Microcystis aeruginosa. Key Eng. Mat. 277, 606-611

Kornijów R. \& Pęczuła W. 2005.- Ecosystem of a small shallow lake suffering from cyanobacterial blooms - hypereutrophic, phytoplankton dominated or both? Verh. Internat. Verein. Limnol. 29, 1015-1019.

Kurmayer R., Christiansen G., Fastner J. \& Börner T.2004.Abundance and active and inactive microcystin genotypes in populations of the toxic cyanobacterium Planktothrix spp. Environ. Microbiol. 6, 831--841.

Laub J., Henriksen P., Brittain S.M., Wang J., Carmichael W.W., Rinehart K.L. \& Moestrup O. 2002.[ADMMAdda(5)]-microcystins in Planktothrix agardhii strain PH-123 (Cyanobacteria) - importance for monitoring of microcystins in the environment. Environ. Toxicol. 1 7, 351-357.

Mbedi S., Welker M., Fastner J. \& Wiedner C. 2005.- Variability of the microcystins synthetase gene cluster in the genus Planktothrix (Oscillatoriales, Cyanobacteria). FEMS Microbiol. Lett., 245, 299-306.

Nixdorf B., Mischke U., \& Rücker J. 2003.- Phytoplankton assemblages and steady state in deep and shallow eutrophic lakes - an approach to differentiate the habitat properties of Oscillatoriales. Hydrobiol. 502, 111- 121.
Park H-D., Iwami C., Watanabe M. F., Harada K-I., Okino T., \& Hayashi H. 1998.- Temporal variabilities of the concentrations of intra-and extra-cellular microcystins and toxic Microcystis species in a hypertrophic lake, lake Suwa, Japan (1991-1994). Environ. Toxicol. Water Qual. 13, 61-72.

Pawlik-Skowrońska B., Skowroński T., Pirszel J., \& Adamczyk A. 2004.- Relationship between cyanobacterial bloom composition and anatoxin-a and microcystin occurrence in the eutrophic dam reservoir (SE Poland). Pol. J. Ecol. 52, 479-490.

Rapala J., Lahti K., \& Niemela S.I. 1994.- Biodegradability and adsorption on lake sediments of cyanobacterial hepatotoxins and anatoxins and anatoxin-a. Lett. Appl. Microbiol. 19, 423-428.

Rohrlack T., \& Hyenstrand P. 2007.- Fate of intracellular microcystins in the cyanobacterium Microcystis aeruginosa (Chroococcales, Cyanophyceae). Phycologia 46, 277-283.

Rücker J., Wiedner C. \& Zippel P. 1997.- Factors controlling the dominance of Planktothrix agardhii and Limnothrix redekei in eutrophic shallow lakes. Hydrobiol. 342/343, 107-115.

Sivonen K. 1990.- Effect of light, temperature, nitrate, orthophosphate and bacteria on growth of and hepatotoxin production by Oscillatoria agardhii strains. Appl. Environ. Microbiol. 56, 2658-2666.

Tonk L., Visser P.M., Christiansen G., Dittmann E., Snelder E.O.F.M., Wiedner C., Mur L.R. \& Huisman J. 2005.- The microcystin composition of the cyanobacterium Planktothrix agardhii changes toward a more toxic variant with increasing light intensity. Appl. Environ. Microbiol.71, 5177-5181.

Tsuji K., Masui H., Uemura H., Mori Y. \& Harada K-I. 2001.Analysis of microcystins in sediments using MMPB method. Toxicon 39, 687-692.

Utermőhl H. 1958.- Zur Vervollkommung der quantitativen Phytoplanktonmethodik. Mitt. Internat. Verein. Limnol. 2, 1-38.

Van Donk E., Faafeng B.A., de Lange H.J., \& Hessen D.O.2001.Differential sensitivity to natural ultraviolet radiation among phytoplankton species in Arctic lakes (Spitsbergen, Norway). Plant Ecol., 154, 249-259.

Verspagen J.M.H., Snelder E.O.F.M., Visser P.M., Huisman J., Mur L.R. \& Ibelings B.W. 2004.-Recruitment of benthic Microcystis (Cyanophyceae) to the water column: internal buoyancy changes or respiration? J. Phycol. 40, 260-270.

Watanabe M.F. \& Oishi S. 1985.- Effects of environmental factors on toxicity of a cyanobacterium (Microcystis aeruginosa) under culture conditions. Appl. Environ. Microbiol. 49, 1342-1344.

Welker M., Christiansen G., \& Van Dohren H. 2004.- Diversity of coexisting Planktothrix (Cyanobacteria) chemotypes deduced by mass spectral analysis of microcystins and other oligopeptides. Arch. Microbiol. 182, 288-298.

Wiedner C., Nixdorf R., Heinze B., Wirsing B., Neumann U. \& Weckesser J.2002.- Regulation of cyanobacteria and microcystin dynamics in polymictic shallow lakes. Arch. Hydrobiol. 155, $383-400$.

Wiedner C., Visser P.M., Fastner J., Metcalf J.S., Codd G.A. \& Mur L.R. 2003.- Effects of light on the microcystin content of Microcystis strain PCC 7806. Appl. Environ. Microbiol. 69, 1475-1481.

Wiśniewska M., Krupa D., Pawlik-Skowrońska B., \& Kornijów R. 2007.- Development of toxic Planktothrix agardhii (Gom.) Anagn. et Komarek and potentially toxic algae in the hypertrophic lake Syczyńskie (Eastern Poland). Oceanol. Hydrobiol. Stud. 36, 173-179. 